\title{
EDITORIAL
}

\section{Pentecostalism around the Baltic Sea}

A longside classical Pentecostalism that had found a foothold in Northern Europe in the early decades of the twentieth century, subsequent trends of charismatic Christianity have also aroused interest as attempts at bringing about a reawakening in what is a, mostly Lutheran, however rather secularised environment. The countries around the Baltic Sea present an intriguing geographical area for the study of Pentecostalism for several reasons. They share a long history of interrelated cultural influences against a backdrop of changing and diverse historical, social and political situations. In addition to other historical connections, a globally significant neo-Pentecostal movement called the Word of Life, which being inspired by the American Faith Movement, originally emerged in Scandinavia, also paved the way for neo-Pentecostalism in the Baltic countries (i.e. Estonia, Latvia and Lithuania) following the collapse of the secularist Soviet regime. This regional viewpoint thus gives an interesting perspective on the transnational dimensions and processes of the religious tradition in question.

This thematic issue of Approaching Religion is based on the papers presented at the two-day seminar 'Pentecostalism around the Baltic Sea' which was held at Åbo Akademi University in May 2014. The seminar was organised by the Centre of Excellence 'Postsecular Culture and a Changing Religious Landscape in Finland' in co-operation with the Donner Institute for Research in Religious and Cultural History in Turku. The event gathered sociologists and anthropologists of religion from nine countries altogether to introduce and discuss the regional and local developments of Pentecostalism from both historical and contemporary perspectives. Nine of the thirteen sem- inar participants have contributed to this issue. The overarching themes of the articles are globalisation, interconnectedness, locality, continuous change in the tradition, and the relationship of Pentecostalism in its many forms to secular cultures.

The so-called 'third wave' of charismatic Christianity was inspired by American antecedents, such as the Vineyard revival and the Faith movement of the late 1970s. The teaching that all 'born-again' believers are able to channel the power of the Holy Spirit; the dynamic culture of worship as 'celebration' and the doctrine of 'health and wealth' are, undoubtedly, the most distinctive characteristics of the neo-Pentecostal movements. In this respect, Sweden has been the centre, among the Nordic countries, from which neoPentecostal ideas have emerged. The influence of the Faith movement through the Word of Life Ministry (Swe. Livets Ord) in Uppsala is recognised as a farreaching inspiration, not only in the Baltic region, but also globally, with a message which combines spiritual, nationalist and economic themes. In this issue, the keynote lecturer of the seminar in Turku, Simon Coleman, reflects on his extensive work on the Word of Life in Sweden and discusses these aspects of the neo-Pentecostal mission and the ways it has become intertwined with the geopolitical processes of the Baltic Sea region.

Reviewing the academic research on Pentecostalism in Sweden, Jan-Åke Alvarsson gives a historical overview of the movement in the country. However, as he points out, even though the national forms of classical Pentecostalism and their relations to neighbouring countries are investigated, the issue of the immigrant churches of today is an area that has so far been mostly left untouched. The forms of Pentecostalism have been categorised, mainly 
along chronological lines, as three, sometimes even as four 'waves'. An increasing diversity of community formations, in styles of worship and in doctrinal emphases, as well as mobility within the regional and local Pentecostal scene poses new challenges in creating typologies of Pentecostal movements. The diverse and for that reason critiqued category of the 'third wave' communities especially raises this question. An attempt to classify Pentecostal communities of today is presented by Jessica Moberg in her article based on ethnography in the Stockholm area. However, in addition to the renewal tendency of neo-Pentecostalism, there is simultaneously an obvious process of institutionalisation going on within traditional Pentecostalism. The Weberian 'routinization of charisma' across the generations is a fact in the old Pentecostal congregations, as Teemu T. Mantsinen points out in his ethnographic study of a local

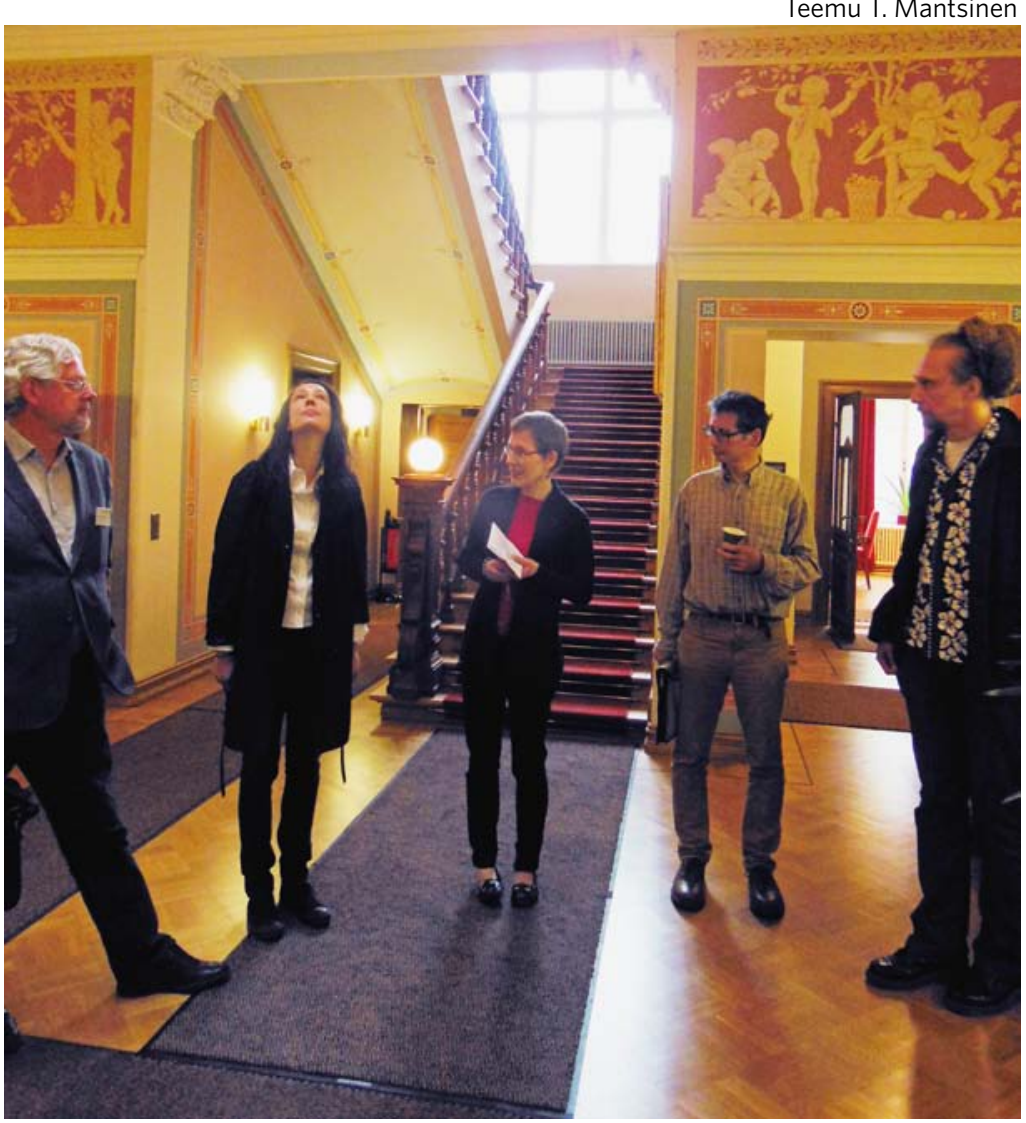

Seminar participants at the Donner Institute: Jan-Åke Alvarsson, Jessica Moberg, Ruth Illman, Simon Coleman and Ringo Ringvee. community in Turku.

What seems to be strikingly different compared to the most prominent areas of expanding Pentecostalism in eastern Asia, Latin America and Africa is that, in many countries in Northern Europe, the actual growth in the numbers of members cannot be verified. Despite the seemingly active and lively charismatic Christian scene, a fixed and permanent commitment to a single congregation simply does not appeal to most of the adult population. As indicated by Mantsinen and Moberg, the number of actual converts is, on the contrary, diminishing, while the most of the active young adherents are brought up in Pentecostal circles. Furthermore, the mobility of the adherents between communities as well as networking regardless of congregational boundaries are aspects that make it difficult to determine the actual membership statistics on the charismatic Christian scene.

The post-Soviet era has opened up more opportunities for revival movements in the three abovementioned Baltic countries. In this issue, the situation in two of these countries, Estonia and Lithuania, is discussed regarding the national influ- ences of Pentecostal and charismatic movements. Ringo Ringvee introduces the development of the Pentecostal scene in Estonia with its early links to Finnish evangelists and, later on, the radical role of the Swedish Word of Life mission in the course of the independence process at the turn of the 1990s. Saulius Matulevicius, for his part, discusses the impact of Pentecostalism in the Catholic milieu of present-day Lithuania. The Catholic charismatic renewal, locally known as the 'inner healing' movement, which has been adopted as a regular form of activity in Catholic parishes is an example of how neo-Pentecostalism has influenced the Christian scene even more widely than merely within the Pentecostal tradition itself. Above all, healing, both bodily and spiritual, is a theme that seems to unify believers of different Christian backgrounds. Tuija Hovi also discusses this theme in her article on the cultural and local accommodations of the Healing Rooms, an intercessory prayer service organisation in Finland. New forms of spiritual communality and border-crossing networks are, indeed, something that neo-Pentecostalism has introduced as an alternative to churchly hierarchy, although not 


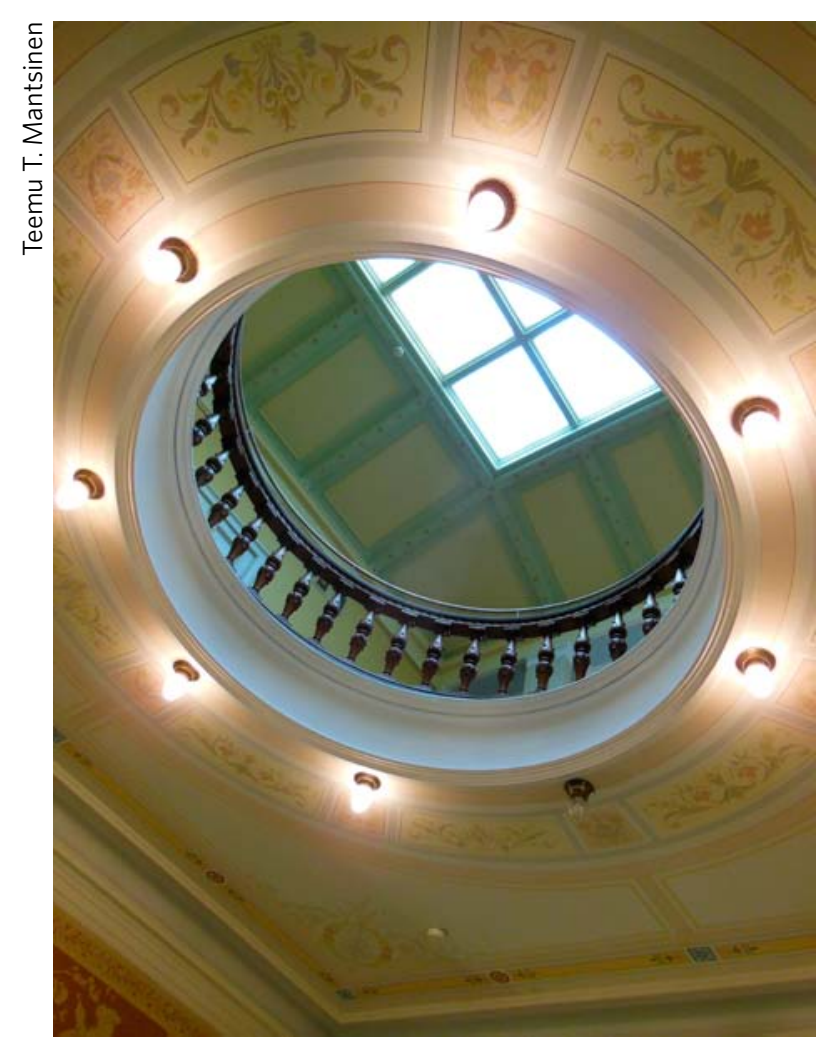

Details of the Humanisticum building which houses the Donner Institute.

without attracting criticism. A Protestant mainline church as the scene of a charismatic renewal is presented by Anna Haapalainen. In her article (forthcoming in this issue), she analyses the discussion on an emerging spirituality which has been inspired by Pentecostalism within a local Finnish Lutheran parish.

Nils G. Holm's extensive research on Pentecostalism in the Swedish-speaking areas of Finland has been recognised internationally. His review in this issue summarises briefly that work and throws light on the interesting theme of creating the narrative for a revival movement. As he points out in the case of Pentecostalism in Finland, behind the official history of the movement lies another story involving significant actors and situations that were deliberately silenced. As Holm indicates, the history of a religious movement can never be considered finally to have been told; what is regarded as historically meaningful is always a question of context. The issue closes with a book review by Dan Sundqvist, dealing with a topical new publication in the field.

The seminar 'Pentecostalism around the Baltic Sea' is not without antecedents. A corresponding seminar in Turku, Pingströrelsen och den karismatiska väckelsen ('The Pentecostal Movement and the Charismatic Revival'), ${ }^{*}$ focussing on the Nordic countries, was held 31 years ago, in 1983 , just before the emergence of the prominent 'third wave' onto the Nordic Pentecostal scene. It was the year that Pastor Ulf Ekman founded the Word of Life Ministry in Uppsala, introducing the neo-Pentecostal teachings and a new form of worship to Sweden and the neighbouring countries. Later on, the Word of Life became one of the most influential neo-Pentecostal movements worldwide. During the early eighties the Iron Curtain continued to divide Europe in two and the countries under the Soviet regime had only a very limited exposure to international influences, including religious ones, until the emergence of national independence processes at the turn of the nineties. The last couple of decades have brought about visible diversifications on the religious scenes of all the countries around the Baltic Sea. The present articles open up perspectives specifically on the study of Pentecostalism - how it has changed, accommodated, assimilated and found new forms of functioning in its Northern European contexts. In the twentyfirst century, Pentecostalism can rather be defined as a style of Christianity than a single movement.

We are pleased to present this timely and engaging issue of Approaching Religion together with a new look for our website. The front page and logo of the journal have been refreshed and updated to better reflect the journal's identity as part of the palette of publications offered online by the Donner Institute and to make navigating the e-journal easier and more pleasant for our readers. We hope you are both analytically and aesthetically stimulated by this issue.

TUIJA HOVI, Guest Editor RUTH ILLMAN, Editor

* Nils G. Holm (ed.): Pingströrelsen och den karismatiska väckelsen: rapporter från ett seminarium $i$ Åbo 1983 (Åbo Akademi, 1984). 